\title{
Health Behavior of Abuan Village Community: Social Dimension Review
}

\author{
Asthadi Mahendra Bhandesa, Putu Indrayoni, and Ni Luh Putu Kartiningsih \\ Bachelor of Nursing Program \\ Institute of Health Sciences (STIKES) Bali \\ Denpasar Bali-Indonesia \\ E-mail: bhandesa_asthadi@yahoo.com/bhandesa_asthadi@stikes-bali.ac.id
}

\begin{abstract}
The development of health is basically an effort to increase awareness, willingness, and the ability of every person to commit a healthy life to achieve the highest level of public health. Health behavior is influenced by several factors including physical, mental, spiritual, and social. This study aims to gain clarity about the social dimensions of the health behavior of the people of Abuan Village, Kecut, Bangli. Data collection in this research using observation, interview, and document study technique. Furthermore, the technique of data analysis is through data reduction or chosen according to research purpose. In the process of data analysis carried out throughout the study or carried out continuously from the beginning to the end of the study. Through the process of systematically tracking and arranging interview transcripts, field notes, and other materials, showed that the social dimension of health behavior in the form of a) human relationship with God; b) human relationships with humans; and c) human relationships with the environment.
\end{abstract}

Keywords: Social dimension, health behavior, interaction, relationships.

\section{INTRODUCTION}

The development of health as a changing process of socio-cultural in the health sector has an important role in improving the quality of life and public health degree. Improving the quality of public health is very important in order to achieve healthy life behavior, therefore it could become a culture. In living, it always facing problems including health development in society, therefore need efforts to improve the development of public health which is not only in terms of health but also from any various aspects that could affect health.

Health is defined as a healthy state, physically, mentally, spiritually, and socially that enables everyone to live socially and economically productive [1]. This perspective of health implies that health is seen from four dimensions of the physical, mental, spiritual and social so that society and every person able to live socially productive in the framework of national development.

The rise of knowledge, awareness, willingness, and ability to live healthy for every person in a healthy environment to realize the optimal status of health in society through the creation of healthy living behavior to realize it as an independent, advanced and prosperous nation. Broadly speaking, the factors that influencing health are grouped into four, the successive effect is the environment, behavior, health care service, and descendants [2].

The empirical understanding and the application of public health behavior tend to be low. There are various factors that influenced because the society socially and culturally has different ways and habits to address health problems in accordance with the social conditions of local communities. To respond to the symptoms of illness, individuals in the community depend on the experience and cultural systems that influence it [3].

Based on preliminary observations, the environment and health conditions of the Abuan Village community have diverse ways of behaving healthily and maintaining their health, including in handling the health problems and environmental hygiene. There is a widespread belief that rural communities have a unique repertoire of public health behaviors that are specifically distinct from urban communities. This all happens mainly influenced by several factors, one of them is a social factor that is believed during this and before. There are several factors that can explain this, those are the belief in society that cannot be separated between health with spiritual power, ceremony, social interaction and so on as a comprehensive health understanding and provide a positive value about health behavior.

Public health behavior is influenced by basic 
understanding and the knowledge of the community and it is associated with local health personnel. Knowledge is the element that plays the most important role that assesses a person's ability to behave in everyday life especially in receiving the things he receives either through the media or face-toface with health workers [4].

Judging from the philosophical, theoretical, and empirical backgrounds, this research becomes very important. This is due to the public health behavior that is influenced by the social dimension which will form a culture of healthy life behavior. The lack of research that discusses the public health behavior of social dimensions is a major reason for the importance of this study, based on the philosophy and objectives of public health behavior, health education is an important part of health development.

\section{METHODOLOGY}

Methodologically, the research was conducted in Abuan Village, Susut Sub-district, Bangli, and then selected as a research setting with consideration that the majority of the population in Abuan Village have several social diversities that influence the unique behavior of public health as a place of change and sustainability of health development towards culture in the form of healthy behavior of society. There are three stages in this study. The first is data collection conducted by field observation, researchers in this case not directly involved in it. As for the object of study is the behavior of public health that greatly influenced by social factors. The process of research done by recorded the data by the recorder and accompanied by notes of the data on findings that are considered important, to avoid data loss. In addition, interview, questionnaires and questioning methods are developed in the field through interview guidelines in accordance with the situation and context encountered during the interview to the depth of the conversation. This method is also supported by document study techniques that are as an effort to support and complete the data of interviews and observations so that the research is clear and complete. Because the object of this study relates to human, culture, and activities of a society, the application of document studies is considered very important. The data analysis method is done by data analysis technique proposed by Miles and Huberman covering three concurrent activities, namely 1) data reduction, 2) data presentation and 3) conclusion (verification) [5]. In the process, data analysis carried out throughout the study and carried out continuously from the beginning to the end of the study through the process of tracking and arranging systematically interview transcripts, field notes, and other materials.

\section{RESULT AND DISCUSSION}

\subsection{Social Dimensions of Community Health} Behavior Abuan Village, Susut, Bangli

Nowadays, individuals always have social relationships with other individuals or groups. Social relationships that occur between individuals and between groups are also known as social interaction. The interaction between the various facets of life that we often experience in everyday life that will form a pattern of relationships that affect each other so that will form a social system in society, this situation is called the social process [6].

Social interaction influences the change of ideas and behavior in society, it is including public health behavior. Behavior is not easy to change. Behavior change is influenced by various factors, such as knowledge, attitude, environment, and many other related factors including social and cultural factors [7]. In Bali people have local wisdom known as Tri Hita Karana, social interaction with local wisdom makes people have a culture in behaving accordingly, it is including in health behavior.

Tri Hita Karana is life guidance based on the concept of the harmony of the relationship between man and God, man and his fellow human beings and his environment in order to achieve a prosperous and spiritual life. Tri hita karana is indeed a noble concept passed by ancestors in the past, to build a prosperous society in the life of Sekala and Niskala $[8,9]$.

Public health behavior can be seen from the social dimension. There are three forms of social dimensions of health behavior: a) human relationships with God, b) human relationships with humans, and c) human relationships with the environment

A. Health Behavior in Relation to Man with God Cultural ceremony or upakara is a tool in realizing the ultimate religious objectives of Santi, Santi, and Santi [10]. This shows that in the human relationship with God, it can be seen in harmony through the form of symbols and tools that are realized to achieve the goal. The dedicated facilities and infrastructure that are implemented in upakara ceremony activities in Abuan Village, Susut Sub-district, Bangli in relation to health behavior.

Abuan villagers have a tendency to use janur and ceremonial materials that are sourced from the garden and in their garden from the house in relation to health. This is not apart from the existence of Abuan village which is geographically a highland area. The wide use of land for agricultural activities shows that most people live as gardeners. Climatologically, the village of Susut has a tropical climate, with an average daily temperature of $30^{\circ} \mathrm{C}$ and rainfall of 6 $\mathrm{mm} /$ year. 
Related to health behavior, the relation of the human relationship with God, Nyoman Partama as a head of BPD bank and also as the responsible of LPD Desa Abuan express as follows.

"Kalau dari hubungan Manusia Dengan Tuhan pasti dalam upacara yadnya masyarakat menggunakan alat-alat upacara yang ada kaitannya dengan kesehatan, utamanya dengan menggunakan buah-buahan yang dari local, selain itu dari segi pengembangan bahan cenderung untuk menggunakan janur yang dipetik langsung dari kebun, dan tidak menggunakan ibung, jika menggunakan ibung tangan sering merasakan gatal, kemungkinan ada zat-zat kimia” "If the relationship of man with God, it must be in the form of yadnya ceremony, people using ceremonies that have relation to health, mainly by using the fruits of the local, in addition in terms of development of materials that tend to use a leaf picked directly from the garden, and not using ibung, if using the ibung by hand, it is often feel itch, moreover there may be chemicals "

The phrase above shows that Abuan Village community has health behavior in the context of a Human relationship with God through the implementation of yadnya ceremony by using the tools and materials that are environmentally friendly. For example, by using a leaf that is obtained directly from the garden or the area around the garden of the house. In the use of ceremonial materials upakara also minimize the use of materials that contain substances containing chemicals. These religious activities play a role in increasing the value of belief and increase tranquility in order to make someone healthy physically and spiritually.

The psychological value is through the knowledge of good and proper prayer procedures that can help focus concentration to gain peace of mind (spiritual health) and gain physical health [11]. Meanwhile, the spiritual values in this stage are the values of the sacred and the unsacred. Through the sincere application of religious teachings, someone can obtain spiritual serenity. Sincerely surrender themselves to Ida Sang Hyang Widhi Wasa will bring someone to spiritual tranquility. This sincerity can ease the sense of suffering experienced because someone has understood the will of Ida Sang Hyang Widhi Wasa and fostered the belief that God will always protect His people (Nada, 2010: 2).

The human relationship with God to the Abuan village community has a high intensity. This belief emerges and is shown by the ceremonial activity of upakara in almost every month, which held in this traditional village. Based on the results of interviews with the Head of Dusun Banjar Susut I Wayan Subakti about the human relationship with God as follows.

"Hubungan manusia dengan Tuhan sangat bagus karena setiap bulan ada upacara agama di desa adat, sehingga masyarakat lebih dekat dan selalu ingat dengan Tuhan, namun dalam hubungan manusia dengan kesehatan, bahwa masyarakat kami masih ada yang kurang perhatian terhadap lingkungan dan kesehatan”

"Human relationship with God is well maintained because every month there is a religious ceremony in this traditional village so that the community closer and always remember with God, but in human relations with health in our society, there is less attention to the environment and health"

Implementation of the ceremony in the human relationship with God that takes place every month in the pakraman village also has little weakness because a small part of society had less attention to health due to the density of the event. Some people prefer the ceremony and piodalan activities. Communities carry out activities in the village solidly. One side produces a lot of physical activity and on the other hand, requires sufficient nutrient intake. People who have less understanding of health will tend to consume less nutritious foods. Physical activity that is regular and sufficient dosage, can help maintain optimal health status for the concerned. Physical activity that is not balanced with the energy consumed, can lead to unbalanced weight with energy that may result in more weight or less weight which may affect the degree of one's health.

Dietary changes will affect nutritional status. The diet is formed through the behavior of food consumption. Incorrect food consumption behavior and poor physical activity cause the body's metabolism to be disrupted which resulting in a condition of more nutrients [12].

The human relationship with God related to the health behavior of the Abuan villagers is carried out using janur and ceremonial materials which are sourced from the garden and in the garden of the house in relation to health. Besides the implementation of the religious ceremony of upakara which almost every month held because it has 13 temples with 26 times of piodalan, high physical activity needs to be maintained with sufficient nutritional intake, but there are still a few who have a lack of understanding of health that is less focused on religious activities so that had less attention of health. A correct understanding of the ways of prayer can help focus on concentration to gain peace of mind (spiritual health) and gain physical health. Through the sincere application of religious teachings, someone can obtain spiritual serenity, alleviate the sense of suffering and foster the belief that God will always protect His people.

\section{B. Health Behavior in Human Relationships with other Humans}

Humans are individual beings who cannot escape their relationships with other human beings. As a result of the relationships between individuals (humans), a group of social groups based on common interests is born [6]. Human relationships with other 
humans will also affect health both physically and psychologically.

The condition of the human body requires a balance of both physical and mental, as well as social and spiritual, potentially inviting various diseases. The situation requires an activity that is beneficial for the health of the body, entertaining activities to avoid the saturation that will interfere with his emotional mental health. To improve physical welfare, one of them is done with an effort to improve the dynamic healthy degree through a suitable health sports activity. Joint activities in the form of physical activity show awareness about health in Abuan village. According to Nyoman Partama, head of BPD Desa Abuan stated as follows.

"Kalau kekerabatan, kami saling memperingati bagaimana menjaga kesehatan bersama. Kalau untuk kegiatan fisik yang mangkin tiang lihat, dari pagi sudah tiang lihat, lansia pagi-pagi sudah ada yang jalan-jalan di sekitar carik, artinya sudah ada kesadaran sedikit tentang kesehatan, secara organisasi memang belum ada, tapi secara perseorangan kelompok ada, misalnya senam dan bagi potensi untuk mengarahkan kesehatan itu bagus",

"If in kinship, we commemorate each other about how to maintain health together. If for the physical activity nowadays, from the morning I had seen, there are elderly in the morning already at streets around the draw, meaning that there is a little awareness about health, organization is not there yet, but individually the group exists, for example, gymnastics and for the potential to lead a good health "

The above statement provides information that human relationships with other humans in health behavior relationships in Abuan village communities in the form of kinship in way of mutual warning about how to maintain health together. The public has the awareness to share information and sharing information related to health in both gymnastics and early morning walks to maintain fitness. So human relationships with other humans are running well. A good relationship is also shown by the public awareness of fellow members of the community by conducting free health checks using self-funds among the Abuan community themselves.

Efforts to improve the health that are sourced from the community have also been carried out routinely in the form of Health Service Integrated Post (Posyandu) in Abuan Village. Health Service Integrated Post is one form of Community-Based Health Efforts (UKBM) managed from, by, for, and with the community, to empower communities and provide convenience to the public in obtaining basic health services [13]. Health Service Integrated Post as an active effort of government and community in improving health through health care for mother, baby, and children under five.
Health Service Integrated Post activities are carried out regularly every month in four Banjar offices in Abuan village, and the community is involved in the form of health cadres that are formed in the village of Abuan members of PKK, Cadres of PHBS and others. The role of cadres in the implementation of Health Service Integrated Post is very large because in addition as a health information provider to the community as well as a leader of the community to come to Health Service Integrated Post and implement a clean and healthy life behavior. In addition, the active role of NGOs also provides many benefits, especially in the form of knowledge through counseling.

Based on the description above, it is known that human relationships with another human about health behavior in Abuan village are in the form of kinship with the commemorate view of how to maintain health together and have the awareness to share health information and conduct free health checks using self-funds by the Abuan village themselves. Efforts to improve the health that are sourced from the community have also been carried out routinely in the form of Health Service Integrated Post in Abuan Village. Posyandu as an active effort of government and community in improving health through health care for mother, baby, and children under five. The community is involved in the form of health cadres that are formed in the village of Abuan member of PKK, Seniors Cadres of PHBS and so forth.

\section{Health Behavior in Relations of Human with the Environment}

Society is one of the main elements in the founding of a country. A prosperous country is a sign that the country has a prosperous society. This prosperity is supported by many factors. One of them is the environmental health of the community in a country

According to the theory of H.L Blum a public health expert, states that the degree of public health is influenced by four main factors namely environment, community behavior, health and genetic [14]. Environmental management includes many preventions, it could be the prevention of damage, pollution, and restoration of environmental quality. It has demanded the development of various policy tools and activity programs supported by other environmental management support systems. The system includes institutional stability, human resources, and environmental partnerships as well as legal and regulatory instruments, information and funding. The interdependence and overall (holistic) nature of the environment have brought the consequences that environmental management, including its support systems, cannot stand alone, but have to be integrated with the whole implementation of the sector and regional development.

Related to environmental management and environmental utilization for public health, the Head 
of BPD Desa Abuan Nyoman Partama stated as follows.

"Kalau lingkungan yang berperan adalah PKK untuk gotong royong setiap Minggu, membersihkan plastik, yang mana sampah sangat tidak baik dalam kesehatan. Bahan bahan itu pasti ada cm yang melakukan itu adalah masyarakat itu sendiri. Namun tiang rasa masyarakat sudah mulai menyadari tentang kesehatan dan pemanfaatan lingkungan, masyarakat sudah menggunakan tumbuh-tumbuhan yang ada di alam. Apapun yang bisa dipergunakan dari apotik hidup langsung dikonsumsi"

"If about the environmental, the one in charge is PKK for held gotong royong every week, to clean the plastic, which is not very good to waste everywhere for health. The material there must be someone that does it, which is the society itself. But the sense of community has started to realize the health and utilization of the environment, people are already using the plants that exist in nature. Anything that can be used from apotik hidup that also able to be consumed directly"

The above statement provides information that the Abuan villagers through PKK cadres participate in maintaining the cleanliness of the environment. By cleaning the waste plastic every week, but the existing waste comes from the community itself, slowly awareness of people in disposing of waste in an appropriate place has begun to increase. On the other hand, the community has also started to realize using plants and pharmacies to live for daily life. Utilization of home garden with greening in the form of a garden basically been suggested in the community to return to nature (back to nature), so that the house will stay beautiful and natural. A life of pharmacy is a term of environmental management (land) planted with nutritious plants for traditional medicine. In environmental management, not all communities have awareness and benefits about how environmental management is good for health.

Environmental management in Abuan Village also has constraints. Environmental management has two dimensions of "integration" and "conflict". Ideally, various environmental management instruments can be formulated in an integrated manner, therefore to accommodate various interest groups. In practice, environmental management cannot be separated from conflict. Therefore, environmental managers must have the capacity to manage conflict from conflicting interests [15]. This problem is the center of attention in the village separated from the order to increase awareness of environmental management to be clean and healthy. As stated by [16] that stated that empowerment is needed to be given whereas the public awareness of the environment is still low.

Improved understanding of clean and healthy environmental management is essential to see that waste can pollute the environment and cause environmental problems. People are required to keep the environment and the natural surroundings stay natural in order to provide benefits, harmonious and not vice versa, which is destroying the environment and natural surroundings. Empowerment measures are needed in the environmental field to build environmental awareness.

Great support and hope from the village on the awareness of clean and healthy environments and how to manage waste by conducting waste management training. In the processing of a clean and healthy environment and free of waste is in very well condition in terms of health because the environment around is the filter to help us avoid various diseases. Waste management and processing can also shape the character of environmental care because by sorting out the garbage and disposing of garbage in place can foster an attitude of respect for the surrounding environment.

Based on the above description, it is known that Abuan villagers have a role in managing the environment and waste processing, human relations with this environment it needs to be developed and enhanced because a healthy and disease-free environment will benefit the entire community, especially on health and environmental conservation.

\section{CONCLUSION}

The social dimension of the health behavior of Abuan villagers is manifested in the form of:

1) Human relationships with God, carried out by using natural ceremonial materials and sourced from the garden or in the garden of the house, the implementation of piodalan every month is held and high physical activity needs to be maintained with adequate nutrition, in addition to the correct understanding concerning the ordinances of prayer can help focus concentration to gain peace of mind (spiritual health) and gain physical health.

2) Human relationships with other humans in the form of kinship by mutually commemorating how to maintain health together and have the awareness to share health information and conduct free health checks using self-funds by the Abuan villagers themselves. The community is involved in the form of health cadres that are formed in the village of a member of PKK, Elderly Cadre, Cadre of PHBS and so forth.

3) Human relationships with Abuan village communities have a role in managing the environment and processing the waste, human relationships with this environment need to continue to be developed and improved because a healthy environment will make us free of disease which will benefit the entire community, especially on health and environmental conservation. 


\section{REFERENCES}

[1] Nomor, U.-U.R.I., tahun 2009 tentang Kesehatan. Lembaran Negara Republik Indonesia Nomor. 144: p. 36.

[2] Basuki, A., S. Dwi Astuti, and S. Sri Darnoto, Hubungan Tingkat Pengetahuan Dengan Perilaku Hidup Bersih Dan Sehat Siswa SD Negeri IV Baturetno Kecamatan Baturetno Kabupaten Wonogiri. 2017, Universitas Muhammadiyah Surakarta.

[3] Arif, S., Manusia dan agama. ISLAMUNA: Jurnal Studi Islam, 2015. 2(2): p. 149-166.

[4] Dahlan, A. and A. Munawar, HUBUNGAN SANITASI LINGKUNGAN DAN FAKTOR BUDAYA DENGAN KEJADIAN TIFUS DI WILAYAH KERJA PUSKESMAS LAMBUR KABUPATEN TANJUNG JABUNG TIMUR TAHUN 2013. Jurnal Ilmiah Universitas Batanghari Jambi, 2017. 14(1): p. 95-101.

[5] Basrowi, S., Memahami penelitian kualitatif. 2008, Jakarta: Rineka Cipta.

[6] Umanailo, M.C.B., S. Sos, and M. Si, Ilmu Sosial Budaya Dasar. Open Science Framework. March, 2018. 17.

[7] Swarjana, I.K. and S. Bali, Ilmu Kesehatan Masyarakat-Konsep, Strategi dan Praktik. 2017: Penerbit Andi.

[8] Sudarsana, I.K. PENGEMBANGAN PENDIDIKAN BERBASIS KEARIFAN LOKAL UNTUK MEWUJUDKAN TOLERANSI ANTAR UMAT BERAGAMA. in Prosiding Seminar Nasional Filsafat. 2017.

[9] Sudarsana, I.K., Optimalisasi Pemahaman Ajaran Tri Hita Karana Dalam Meningkatkan Karakter Siswa Sekolah Dasar (Perspektif Psikologi Pendidikan). Prosiding Senada 2, 2017: p. 250-256.

[10] Sudarsana, I.K., Pengantar Pendidikan Agama Hindu. 2018.

[11] Kristhina, N.M.I., EKSISTENSI PURA LUHUR TAMBAWARAS DI DESA SANGKETAN KECAMATAN PENEBEL KABUPATEN TABANAN. Jurnal Penelitian Agama Hindu, 2017. 1(2): p. 41-49.

[12] Junaz, N.S. and A. Siagian, Hubungan Perilaku Konsumsi Makanan dengan Status Gizi PNS BAPPEDA Kabupaten Langkat Tahun 2015. Gizi, Kesehatan Reproduksi dan Epidemiologi, 2016. 1(5).

[13] Kementrian Kesehatan, R., Buku Saku Posyandu. Jakarta: Kemenkes RI, 2012.

[14] Yudhastuti, R., PERUBAHAN IKLIM: PREDIKSI DAN PENGENDALIAN PENYAKIT YANG DITULARKAN BINATANG Disampaikan pada Pengukuhan jabatan Guru Besar dalam Bidang IImu Kesehatan Lingkungan pada Fakultas Kesehatan Masyarakat Universitas Airlangga di Surabaya pada Hari Sabtu, Tanggal 8 juli 2017. 2017.
[15] GEUMALA, M., Y.E. Pratiwi, and M. Ali, MANAJEMEN LINGKUNGAN KESEHATAN PERKOTAAN. 2018.

[16] Susilo, D. and K. Rachmad, Sosiologi Lingkungan \& Sumber Daya Alam. Jogjakarta. Ar-Ruzz Media, 2012. 